\title{
Generation and characterization of the MCF-7 cell line with a knockout of a p85-S6K1 isoform of the ribosomal protein S6 kinase 1
}

\author{
V. V. Holiar, N. Ya. Gotsulyak, A. I. Khoruzhenko, I. V. Zaiets \\ Institute of Molecular Biology and Genetics, NAS of Ukraine \\ 150, Akademika Zabolotnoho Str., Kyiv, Ukraine, 03143 \\ zaiets.i@gmail.com
}

\begin{abstract}
Aim. To generate the p85-S6K1 knockout MCF-7 breast cancer cell line and to evaluate the effect of p85-S6K1 on cell growth, migration and survival under stress conditions. Methods. CRISPR/Cas9 genome editing, Western blotting, immunofluorescence staining, MTT assay, in vitro scratch assay. Results. We generated two clones of the p85-S6K1 knockout MCF-7 cell line and tested their survival upon hydrogen peroxide treatment as well as the proliferation and migration rates. The generated cell clones display an impaired ability to survive under oxidative stress, exhibit inhibition of cell growth, cell motility and downregulation of rpS6 phosphorylation on Ser235/236/240/244 under cell starvation compared to the control cells. Conclusions. The p85-S6K1 isoform could be involved in modulation of cancer cell behaviour promoting cell growth, migration and survival. The obtained clones can be further used to study the participation of different S6K1 isoforms in the control of cell function.
\end{abstract}

Keyword s: mTOR/S6K1 signaling, CRISPR/Cas9, p85-S6K1 isoform.

\section{Introduction}

S6 ribosomal protein kinase 1 (S6K1) is an extensively studied serine/threonine protein kinase which functions as a component of the mTOR/S6K1-dependent signaling pathway. It is involved in the regulation of protein, lipid and nucleotide synthesis as well as cell proliferation, survival, motility and other cellular processes (reviewed in $[1,2]$ ). Overactivation of this kinase leads to the development of a number of disease states, including obesity, diabetes and cancer (reviewed in [2-4]). For example, S6K1 is frequently overexpressed in breast, lung, ovary, endometrial and thyroid cancers [5-9]. Its expression correlates with poor prognosis in patients with breast, kidney and hepatocellular carcinomas which makes S6K1 a potential therapeutic target for cancer treatment (reviewed in [5]). Furthermore, dysregulation of $\mathrm{mTOR} / \mathrm{S} 6 \mathrm{~K} 1$ signaling is of special significance in breast cancer. This signal-

(C) 2019 V. V. Holiar et al.; Published by the Institute of Molecular Biology and Genetics, NAS of Ukraine on behalf of Biopolymers and Cell. This is an Open Access article distributed under the terms of the Creative Commons Attribution License (http://creativecommons.org/licenses/by/4.0/), which permits unrestricted reuse, distribution, and reproduction in any medium, provided the original work is properly cited 
ing pathway undergoes overactivation in approximately $70 \%$ of breast tumors (reviewed in $[10,11])$. Indeed, the S6K1 gene is commonly amplified during this disease which may have prognostic and treatment predictive significance $[12,13]$.

S6K1 is represented by two major isoforms - p85- and p70-S6K1. p85-S6K1 possesses the additional $\mathrm{N}$-terminal 23 amino acid extension which harbours a six-tandem arginine repeat (6R motif) and nuclear localization signal (NLS). These isoforms are synthesized by the utilization of alternative translation start codons - the first one for p85-S6K1 and the second one for p70-S6K1 [14]. According to the existing data, the usage of another alternative translation start site (the third ATG) may yield the expression of the additional p60$\mathrm{S} 6 \mathrm{~K} 1$ isoform which is 53 a.a. shorter from the N-terminus than $\mathrm{p} 85$-S6K1 and has an intact kinase domain [15]. It has also been discovered that the splicing factor ASF/SF2 promotes the expression of the oncogenic kinase-dead S6K1 splice variant termed $\mathrm{p} 31$ $\mathrm{S} 6 \mathrm{~K} 1$ that is truncated from the $\mathrm{C}$-terminus [16]. This isoform was shown to directly interact with and activate mTORC1 which leads to the enhanced cap-dependent translation and subsequent cancer progression [17].

It has recently been shown that the p85S6K1 isoform can be secreted by cancer cells and enter surrounding ones in a manner that depends on a six-tandem arginine repeat on its N-terminus that facilitates cancer cell growth, proliferation and migration [18]. Nevertheless, the exact functional difference between p85- and p70-S6K1 isoforms still remains unclear. Hence, the aim of this study was to generate the p85-S6K1 knockout MCF-
7 breast cancer cell lines using the CRISPR/ Cas9 genome editing technology and to evaluate their ability to survive under stress conditions, grow and migrate. Here, we demonstrate that p85-S6K1 knockout results in the inhibition of all the above-mentioned processes. The obtained data revealed that $\mathrm{p} 85$-S6K1 might play a role in the cancer progression and could be used as a potential therapeutic target for cancer treatment.

\section{Materials and Methods}

CRISPR gRNA design and cloning. gRNA design was performed using the web tool http://crispr.mit.edu/. A pair of oligonucleotides to target the S6K1 gene region that corresponds to the p85 N-terminal extension is the following:

top strand - 5'-CACCGAGCCCCGGAC TTCCGAGACA-3',

bottom strand - 5'-AAACTGTCTCGGAA GTCCGGGGCTC-3',

where sequences in bold correspond to the BbsI restriction site. Complementary oligonucleotide duplexes were ligated with the pSpCas9(BB)-2A-Puro (PX459) V2.0 cloning vector which is driven by the U6 promoter and encodes the Cas9 endonuclease necessary for gRNA functioning. The presence of the insert was verified by PCR amplification and sequencing (Applied Biosystems ${ }^{\mathrm{TM}} 3130$ DNA Analyzer). The U6 primer was applied as a forward one (5'-GAGGGCCTATTTCCCATGATTCC-3') and the oligonucleotide corresponding to the bottom gRNA strand was employed as a reverse primer (5'-AAACTGTCTCGGAAGTCCGGGGCTC-3').

Cell culture and transfection. The MCF-7 breast cancer cell line and its mutant deriva- 
tives were cultured at $37{ }^{\circ} \mathrm{C}\left(5 \% \mathrm{CO}_{2}\right)$ in Dulbecco's Modified Eagle's Medium (DMEM) supplemented with $10 \%$ fetal bovine serum (FBS, GIBCO), 100 units/ml penicillin and $100 \mu \mathrm{g} / \mathrm{ml}$ streptomycin. Transfection of MCF-7 cells was performed with jetPEI ${ }^{\circledR}$ transfection reagent (Polyplus-transfection ${ }^{\circledR}$ SA) following manufacturer's instructions. Cells were seeded onto a 24-well plate, grown for 24 hours and thereafter transfected with $1 \mu \mathrm{g}$ of DNA (pSpCas9(BB)-2A-Puro (PX459) $\mathrm{V} 2.0+$ anti-p85 gRNA). Then cells were seeded onto $10-\mathrm{cm}$ cell culture dishes $24 \mathrm{~h}$ posttransfection and selected with puromycin $(4 \mu \mathrm{g} / \mathrm{mL})$ for another $24 \mathrm{~h}$. Single clones were isolated for further analysis.

Western blot analysis. Cells were lysed on ice for $30 \mathrm{~min}$ in $25 \mathrm{mM}$ Tris-HCl, $\mathrm{pH} 7.5$, $150 \mathrm{mM} \mathrm{NaCl}, 1 \mathrm{mM}$ EDTA, $0.5 \%$ Triton $\mathrm{X}-100,5 \%$ glycerol, $1 \mathrm{mM} \mathrm{Na} \mathrm{VO}_{4}, 2.5 \mathrm{mM}$ $\mathrm{Na}_{4} \mathrm{P}_{2} \mathrm{O}_{7}, 1 \mathrm{mM} \beta$-glycerophosphate supplemented with a cOmplete ${ }^{\mathrm{TM}}$ EDTA-free protease inhibitor cocktail tablet (Roche) and phosphatase inhibitors (Sigma-Aldrich). Whole-cell lysates were centrifuged at $12,000 \mathrm{x} \mathrm{g}$ for $10 \mathrm{~min}$ at $4{ }^{\circ} \mathrm{C}$ and the supernatant was collected. Protein concentrations were determined using Bradford assay (Pierce Coomassie Protein Assay Kit, Thermo Scientific). Whole-cell lysates were resolved by $10 \%$ SDS-PAGE and then transferred onto a polyvinylidene difluoride (PVDF) membrane (Immobilon ${ }^{\circledR}-\mathrm{P}$, Millipore). The membrane was blocked with $5 \%$ low-fat milk in TBS-T (50 mM Tris-HCl, pH 7.4, $150 \mathrm{mM}$ $\mathrm{NaCl}, 0.1 \%$ Tween-20) and after that incubated with primary antibodies used according to the manufacturer's instructions. Following this, secondary antibodies linked to horserad- ish peroxidase (obtained from Jackson ImmunoResearch) were diluted 1:10000 and incubated at room temperature for 1 hour. Proteins of interest were revealed using enhanced chemiluminescence reagent (GE Healthcare). Primary antibodies were used as follows: anti-S6K1-C-terminus (generated as described in [19]) 1:2500, anti-p85-S6K1-Nterminus (generated as described in [20]) 1:2500, anti- $\beta$-actin (clone AC-15, \#A5441, Sigma-Aldrich) 1:20000, anti-phopho-S6 ribosomal protein (Ser235/236, \#2211, Cell Signaling Technologies) 1:2000, anti-phospho-S6 ribosomal protein (Ser240/244, \#5364, Cell Signaling Technologies) 1:2000, anti-phospho-Akt (Ser473, \#9271, Cell Signaling Technologies) 1:2000.

Immunofluorescence staining. All the cell lines used in this study were grown on the glass coverslips and fixed in $10 \%$ neutral buffered formalin for $15 \mathrm{~min}$. Cells were then permeabilized using $0.2 \%$ Triton X-100 and incubated in blocking solution (10\% fetal calf serum in PBS) for 30 min. After blocking, cells were treated with primary antibodies against the p85-S6K1 N-terminus [20] diluted 1:100 overnight at $4{ }^{\circ} \mathrm{C}$. Coverslips were washed with PBS and then labeled with FITC-tagged secondary antibodies (Jackson ImmunoResearch) diluted 1:400 for $1 \mathrm{~h}$ at room temperature. Samples were further mounted on microscope slides using the Mowiol ${ }^{\circledR}$ medium (Sigma-Aldrich) supplemented with $2.5 \%$ $\mathrm{DABCO}^{\circledR}$ (Sigma-Aldrich) and $0.5 \mathrm{mg} / \mathrm{ml}$ DAPI (Thermo Scientific) for autofluorescence elimination and cell nuclear staining, respectively. The immunostained cells were examined using a Zeiss LSM 510 META microscope (Germany). 
MTT assay (Cell survival and proliferation). To examine a cellular response to oxidative stress, cells were seeded in a 96-well culture plate at a density of 15000 cells in $100 \mu$ of DMEM supplemented with $10 \%$ FBS per well. Each cell line was cultured in the presence of $100 \mu \mathrm{M} \mathrm{H}_{2} \mathrm{O}_{2}$ or without it (positive control) for $36 \mathrm{~h}$. At the end of incubation, $20 \mu \mathrm{lof} 5 \mathrm{mg} / \mathrm{ml}$ MTT (3-(4,5-dimethylthiazol-2-yl)-2,5-diphenyltetrazolium bromide) were added to each well. Following incubation with MTT for $3 \mathrm{~h}, 150 \mu \mathrm{l}$ of DMSO were added to dissolve formazan crystals and then absorbance was measured at $570 \mathrm{~nm}$ (BioTek ELx800, BioTek Instruments, Inc.). Experiments were performed in triplicate. To estimate cell proliferation, cells were seeded in a 96well culture plate at a density of 5000 cells and incubated in $100 \mu \mathrm{l}$ of DMEM supplemented with $10 \%$ FBS for $72 \mathrm{~h}$. At the end of incubation, $10 \mu \mathrm{l}$ of $5 \mathrm{mg} / \mathrm{ml}$ MTT were added to each well and samples were incubated for $2 \mathrm{~h}$. After that, $150 \mu \mathrm{l}$ of DMSO were added to dissolve formazan crystals and absorbance was measured at $570 \mathrm{~nm}$. Experiments were carried out in triplicate.

In vitro scratch assay. Cells were plated onto a 35-mm dish and grown until $100 \%$ confluence to form a monolayer. A scratch was created with a $200 \mu \mathrm{l}$ pipette tip across the diameter of the dish. Then cells were washed once with PBS and replaced with fresh medium. At time points of 0 and $48 \mathrm{~h}$ of incubation, cells were examined using the Leica DM 1000 microscope and images of a created wound were acquired using a digital camera. The average distance $(\mu \mathrm{m})$ between wound sides was measured at each time point using the ImageJ software and obtained values were used to calculate the migrated distance. Each experiment was repeated at least three times.

Statistical analysis. All experiments were performed in triplicate and the mean values were indicted in the graphs. The statistical difference (standard deviation, $\pm \mathrm{SD}$ ) and $\mathrm{p}$ values were calculated using ANOVA $(p<0.01$ was considered to be significant).

\section{Results and Discussion}

As it was already mentioned, p85- and $\mathrm{p} 70-\mathrm{S} 6 \mathrm{~K} 1$ isoforms are synthesized from the common transcript by the utilization of alternative ATG start codons and differ by the additional $\mathrm{N}$-terminal extension unique to $\mathrm{p} 85$ (Fig. 1, A). Thus, in order to selectively disrupt the expression only of p85-S6K1, we designed a gRNA oligonucleotide (20 $\mathrm{nt}$ in size) that corresponds to 175-194 nt in the S6K1 mRNA coding sequence for targeting the S6K1 gene region located between the first and second start codons (Fig. 1, B). p85-S6K1 knockout was performed in the MCF-7 cell line using a DNA vector which encodes both the Cas9 endonuclease and the designed gRNA. After selection, individual clones were analyzed by Western blot and immunofluorescence staining using anti-S6K1 antibodies specific to its $\mathrm{C}$-terminal region and p85 N-terminal extension. According to the Western blot analysis, we generated two clones with a complete loss of p85-S6K1 (Fig. 2). Noteworthy, however, both clones also displayed decreased levels of $\mathrm{p} 60$ - and $\mathrm{p} 70-\mathrm{S} 6 \mathrm{~K} 1$ expression, although reduction of p60/p70-S6K1 expression in the clone 2 was moderate in contrast to the clone 1 that exhibited significantly reduced expression of the indicated isoforms. Both generated MCF-7 clones with the disrupted expression 
A

\begin{tabular}{|c|c|c|c|}
\hline p85-S6K1 & NLS & Kinase domain & C-terminal \\
\hline
\end{tabular}

p70-S6K1

\begin{tabular}{l|l|l|l} 
Kinase domain & & C-terminal
\end{tabular}

B

S6K1 gene

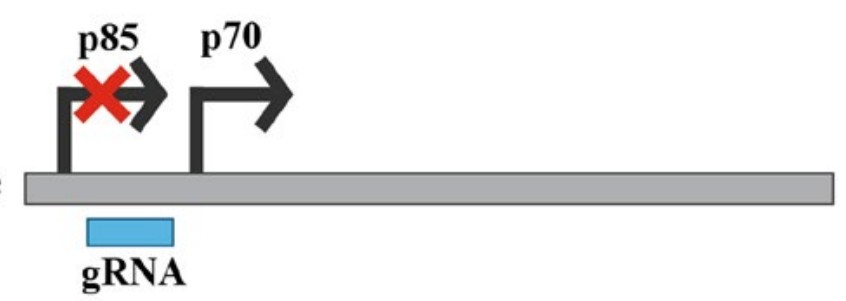

Fig. 1. Generation of the MCF-7 cell line with p85-S6K1 knockout. (A) Schematic representation of p85- and p70S6K1 domain organization. (B) gRNA design for the S6K1 gene editing using the CRISPR/Cas9 system.

of the $\mathrm{p} 85-\mathrm{S} 6 \mathrm{~K} 1$ isoform were further analyzed by immunofluorescence staining with anti-p85S6K1 antibodies. Similar to the results of Western blot analysis, the data of immuno-

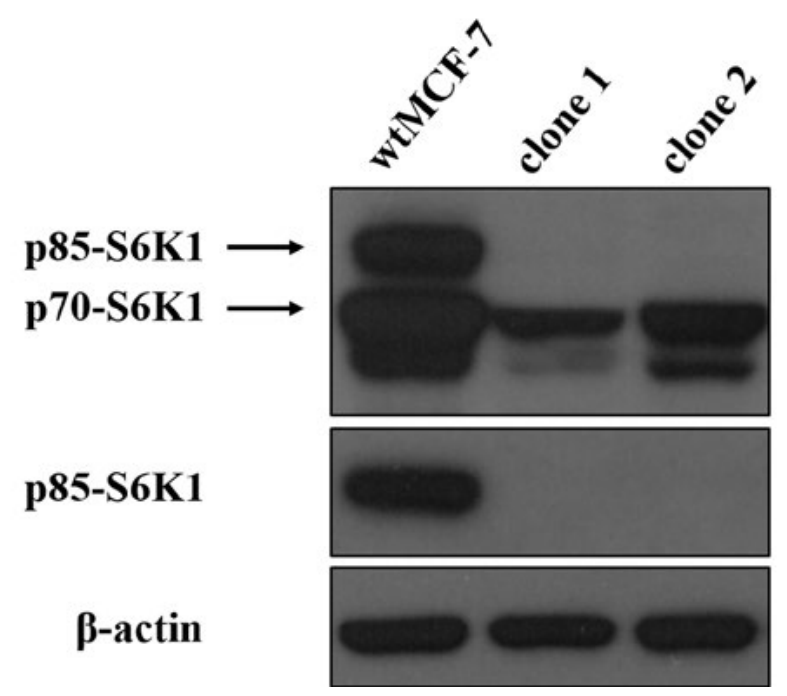

Fig. 2. p85-S6K1 knockout confirmation by immunoblot analysis with antibodies specific to both the S6K1 C-terminus and p85-specific amino acid sequence. Clone 1 and 2 - MCF-7 cells without p85-S6K1 expression. Equal protein loading was confirmed by $\beta$-actin detection. fluorescence staining confirmed the complete loss of p85 (Fig. 3).

S6K1 is known to influence cell viability acting as both pro- and antiapoptotic protein depending on the action of various extracellular factors (reviewed in [2]). According to the recent data, $\mathrm{p} 85$, but not $\mathrm{p} 70$, can promote cell death under oxidative stress interacting with IKK- $\beta$ which is a component of NF- $\kappa \mathrm{B}$ signaling [21]. To reprove this observation, we decided to examine how MCF-7 cells with p85-S6K1 knockout would survive under hydrogen peroxide treatment. For this purpose, we applied MTT assay and found that both clones with the disrupted expression of $\mathrm{p} 85$ showed an impaired ability to survive compared to wild-type cells (Fig. 4, A) which is opposite to the results obtained by the Jia group [21]. It could be explained by the fact that the MCF-7 cell line is quite genetically unstable and some differences in genetic material may have influenced the obtained data [22]. Furthermore, in both cases different approaches to silence p 85 expression and to es- 


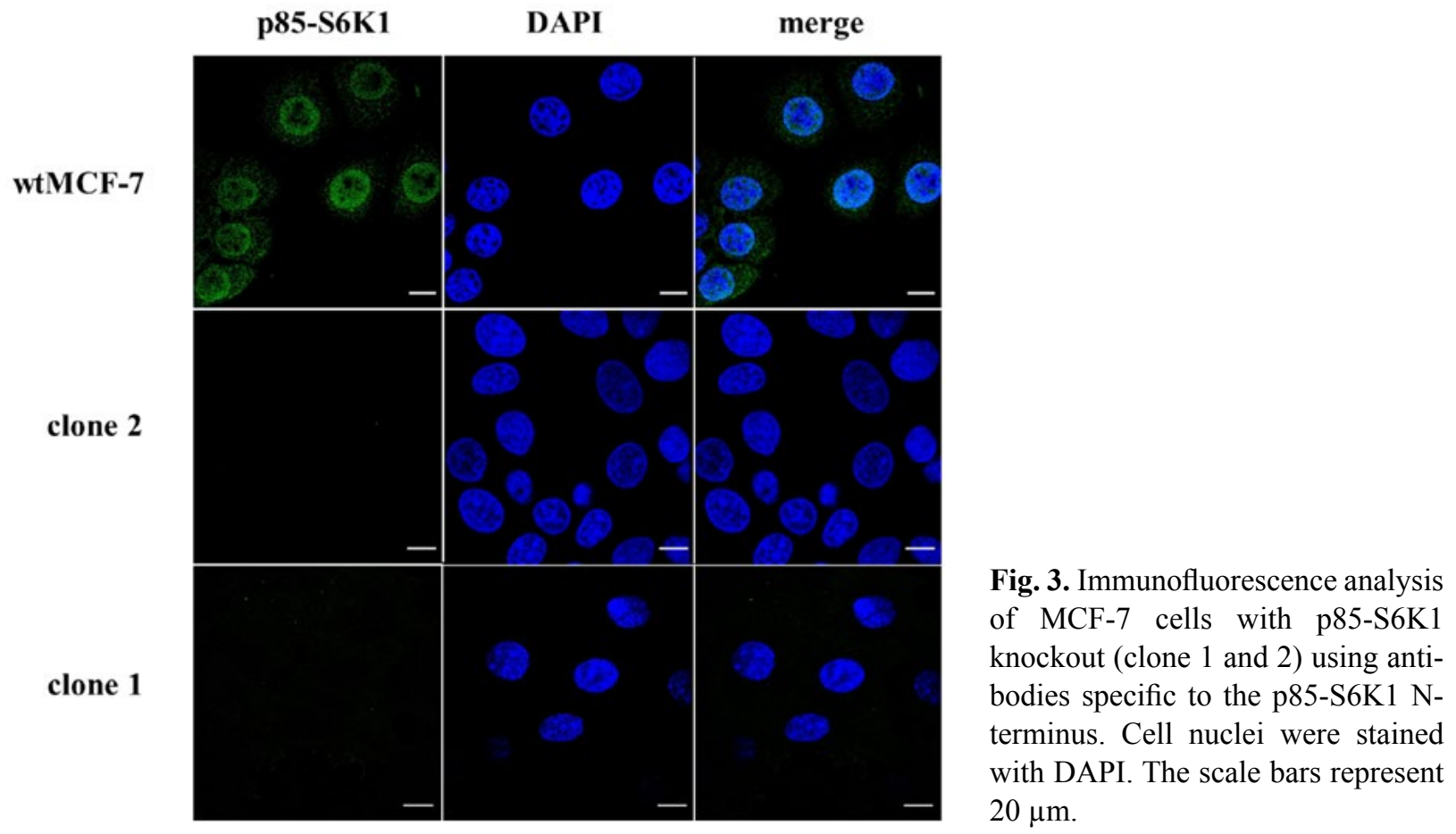

timate cell viability were applied that could also have a certain impact.

As current evidence suggests, S6K1 regulates cell growth via control of protein, lipid and nucleotide synthesis (reviewed in [1]), thus influencing cell cycle progression. Under certain circumstances, S6K1 can also modulate cell proliferation independently of cell growth control by inactivation of GSK3 [23] and stimulation of $\mathrm{ER} \alpha$ transcriptional activity that is especially significant for HR-positive type of breast cancer (reviewed in [10]). It has recently been shown that p85 itself is able to enhance cell proliferation of MEFs and MDAMB-231 breast cancer cells and to facilitate tumor growth in vivo [18]. Upon p85-S6K1
$\boldsymbol{A}$

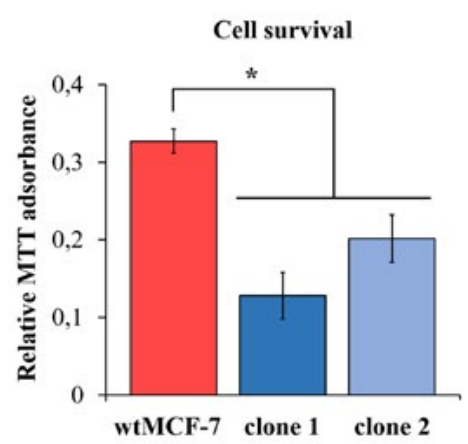

B

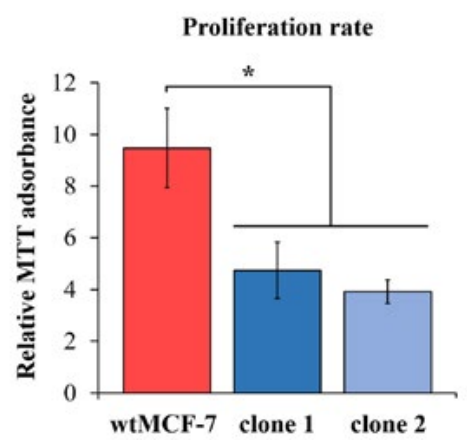

Fig. 4. Evaluation of cell survival and proliferation under hydrogen peroxide treatment by the MTT assay. Bars represent the mean \pm S.D. for three independent experiments. $*-\mathrm{p}<0,01$ versus wtMCF-7. $A-$ Cells were treated with $100 \mu \mathrm{M}$ $\mathrm{H}_{2} \mathrm{O}_{2}$ for 36 hours. $B-$ Cells were grown in complete cell culture medium (supplemented with $10 \% \mathrm{FBS}$ ) for $72 \mathrm{~h}$. 
knockout, we observed a reduction in the proliferation rate of both clones compared to the wild-type MCF-7 cells (Fig. 4, B) that is consistent with the results described above.

Additionally, S6K1 is involved in the regulation of cell motility facilitating cell migration and invasion, which is crucial for cancer metastasis [24-26]. p85-S6K1 was shown to be able to individually stimulate migration of MCF10A cells and lung metastasis in vivo [18]. To examine a migration rate of MCF-7 cells with p85-S6K1 knockout, we applied the in vitro scratch assay and revealed a visible inhibition of this process in both clones (Fig. 5) A

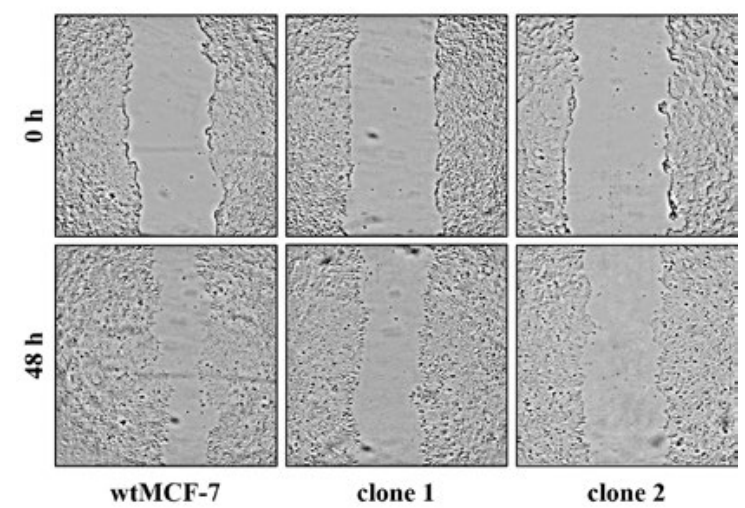

B

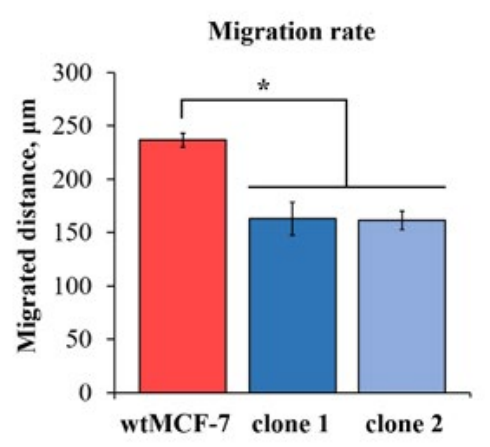

Fig. 5. Analysis of cell migration by the in vitro scratch assay. $A$ - Images were captured after 0 and $48 \mathrm{~h}$ of incubation. $B-$ Bars represent the mean \pm S.D. for three independent experiments. ${ }^{*} \mathrm{p}<0.01$ versus wtMCF-7. that further supports an important role of $\mathrm{p} 85$ isoform in the control of cell motility.

We also estimated an impact of the p85S6K1 knockout on the phosphorylation level of its major substrate ribosomal protein S6 (rpS6) on different sites and the phosphorylation level of Akt. Phosphorylation of rpS6 is essential for the activation of the ribosome biogenesis transcriptional program which affects global protein synthesis [27]. According to our data, the phosphorylation level of rpS6 on Ser235/236/240/244 was significantly decreased after p85-S6K1 knockout in MCF-7 cells compared to the wildtype ones during cell starvation. This suggests a possible role of these phosphorylation events mediated by the p85-S6K1 isoform in cell survival under stress conditions (Fig. 6). Furthermore, the extent of serum-induced phosphorylation of rpS6 was lower in cells with

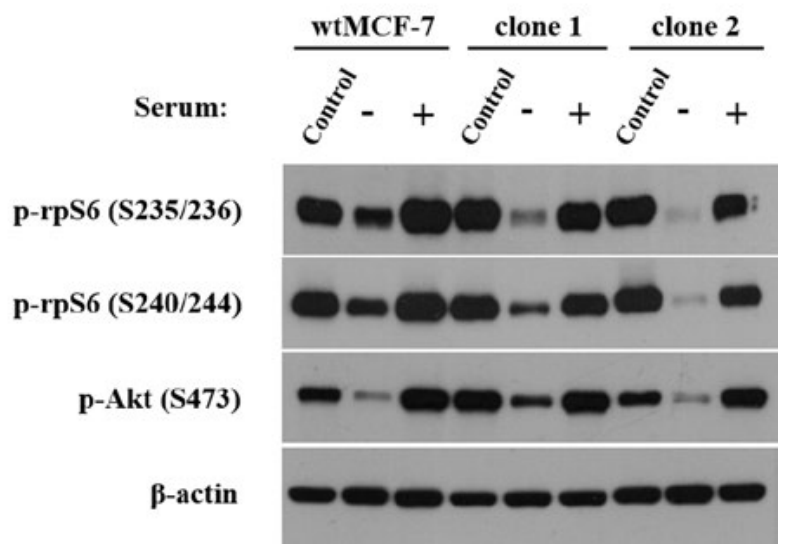

Fig. 6. Alterations in Akt/mTOR signaling under the CRISPR/Cas9-mediated p85-S6K1 knockout in MCF-7 cells. The wild-type MCF-7, clone 1 and 2 cells were starved in serum-depleted DMEM for $24 \mathrm{~h}$ and then restimulated with $20 \%$ FBS for 1 hour. Cell lysates were analyzed by Western blotting using the indicated antibodies. Clone 1 and $2-$ MCF-7 cells without p85-S6K1 expression. Antibodies against $\beta$-actin were applied to confirm equal protein loading. 
disrupted expression of $\mathrm{p} 85-\mathrm{S} 6 \mathrm{~K} 1$. The phosphorylation level of rpS6 under basal conditions was not considerably altered that may be explained by the existence of compensatory mechanisms, including phosphorylation mediated by p70-S6K1 isoform, RSK (phosphorylates rpS6 on Ser235/236, reviewed in [28]) and S6K2 (promotes phosphorylation of $\mathrm{rpS} 6$ on Ser235/236/240/244, reviewed in [29]). S6K1 is known to inhibit the Akt activity via phosphorylation of IRS1 creating a negative feedback loop [30, 31]. Thus, we also analyzed the Akt phosphorylation status in the generated clones at the Ser 473 site that is critical for the Akt kinase activity [3]. Our data demonstrate that the Ser473 phosphorylation pattern of Akt in the p85-S6K1 knockout MCF-7 cells is similar to the one in the wild-type counterparts (Fig. 6), implying that p85-S6K1 might not be involved in regulation of the Akt kinase activity.

Considering that both studied clones also had reduced expression of $\mathrm{p} 70-\mathrm{S} 6 \mathrm{~K} 1$, it could be possible that a decline in $\mathrm{p} 70-\mathrm{S} 6 \mathrm{~K} 1$ expression was responsible for inhibition of all the cellular processes tested in the study. Noteworthy, however, each clone possesses a different level of p70-S6K1 knockdown and our data do not show any correlation between a decrease in $\mathrm{p} 70-\mathrm{S} 6 \mathrm{~K} 1$ expression and cell proliferation/migration rates, except for the ability of cells to survive. Still, we cannot exclude a possibility of at least a partial negative impact of p70-S6K1 downregulation on the mentioned cellular processes in the created $\mathrm{MCF}-7$ clones.

In conclusion, our findings suggest that the p85-S6K1 isoform could promote malignant cell behaviour regulating cell growth, migration and survival. The generated MCF-7 cell line could be further used to get deeper understanding of a separate impact of different S6K1 isoforms on the control of cell function. Deciphering the difference between functional properties of distinct S6K1 isoforms is crucial for the development of novel treatment strategies which might rely upon targeting only specific S6K1 isoforms but not the whole pool of S6K1. This could potentially make these treatments more efficient and reduce a number of possible side effects.

\section{REFERENCES}

1. Shimobayashi M, Hall MN. Making new contacts: the mTOR network in metabolism and signalling crosstalk. Nat Rev Mol Cell Biol. 2014;15(3):155-62.

2. Tavares MR, Pavan IC, Amaral CL, Meneguello L, Luchessi AD, Simabuco FM. The S6K protein family in health and disease. Life Sci. 2015;131:1-10.

3. Magnuson B, Ekim B, Fingar DC. Regulation and function of ribosomal protein S6 kinase (S6K) within mTOR signalling networks. Biochem $J$. 2012;441(1):1-21.

4. Dann SG, Selvaraj A, Thomas G. mTOR Complex1S6K1 signaling: at the crossroads of obesity, diabetes and cancer. Trends Mol Med. 2007;13(6):252-9.

5. Pópulo H, Lopes JM, Soares P. The mTOR signalling pathway in human cancer. Int $J$ Mol Sci. 2012;13(2): 1886-918.

6. Lyzogubov V, Khozhaenko Y, Usenko V, Antonjuk S, Ovcharenko G, Tikhonkova I, Filonenko V. Immunohistochemical analysis of Ki-67, PCNA and S6K1/2 expression in human breast cancer. Exp Oncol. 2005;27(2):141-4.

7. Lyzogubov VV, Lytvyn DI, Dudchenko TM, Lubchenko NV, Pogrybniy PV, Nespryadko SV, Vinnitska AB, Usenko VS, Gout IT, Filonenko VV. Immunohistochemical analysis of S6K1 and S6K2 expression in endometrial adenocarcinomas. Exp Oncol. 2004;26(4):287-93.

8. Lytvyn DI, Dudchenko TM, Lyzogubov VV, Usenko VS, Nespryadko SV, Vinnitskaya AB, Vorobyo- 
va LI, Pal'chevskiy SS, Filonenko VV, Pogrebnoy $P V$. Expression of $\alpha$ - and $\beta$-isoforms of p70S6 kinase in human endometrial tumors. Exp Oncol. 2003;25(4):274-8.

9. Lyzogubov VV, Usenko VS, Khojaenko YuS, Lytvyn DI, Soldatkina MA, Rodnin NV, Filonenko VV, Pogribniy $P V$. Immunohistochemical analysis of p70S6 kinase $\alpha$ in human thyroid tissue upon pathology. Exp Oncol. 2003;25(4): 304-6.

10. Holz $M K$. The role of S6K1 in ER-positive breast cancer. Cell Cycle. 2012;11(17):3159-65.

11. Liu J, Li HQ, Zhou FX, Yu JW, Sun L, Han ZH. Targeting the mTOR pathway in breast cancer. Tumour Biol. 2017;39(6):1-15.

12. Sinclair CS, Rowley M, Naderi A, Couch FJ. The 17q23 amplicon and breast cancer. Breast Cancer Res Treat. 2003;78(3):313-22.

13. Pérez-Tenorio G, Karlsson E, Waltersson MA, Olsson B, Holmlund B, Nordenskjöld B, Fornander T, Skoog L, Stål O. Clinical potential of the mTOR targets S6K1 and S6K2 in breast cancer. Breast Cancer Res Treat. 2011;128(3):713-23.

14. Grove JR, Banerjee P, Balasubramanyam A, Coffer PJ, Price DJ, Avruch J, Woodgett JR. Cloning and expression of two human p70 S6 kinase polypeptides differing only at their amino termini. Mol Cell Biol. 1991;11(11):5541-50.

15. Kim D, Akcakanat A, Singh G, Sharma C, MericBernstam $F$. Regulation and localization of ribosomal protein S6 kinase 1 isoforms. Growth Factors. 2009;27(1):12-21.

16. Karni R, de Stanchina E, Lowe $S W$, Sinha $R, M u D$, Krainer $A R$. The gene encoding the splicing factor SF2/ASF is a proto-oncogene. Nat Struct Mol Biol. 2007;14(3):185-93.

17. Ben-Hur V, Denichenko P, Siegfried Z, Maimon A, Krainer A, Davidson B, Karni R. S6K1 alternative splicing modulates its oncogenic activity and regulates mTORC1. Cell Rep. 2013;3(1):103-15.

18. Zhang J, Guo J, Qin X, Wang B, Zhang L, Wang Y, Gan $W$, Pandolfi PP, Chen $W$, Wei $W$. The p85 isoform of the kinase S6K1 functions as a secreted oncoprotein to facilitate cell migration and tumor growth. Sci Signal. 2018;11(523).
19. Savinska LO, Kijamova RG, Pogrebnoy PV, Ovtsharenko GV, Gout IT, Filonenko VV. Comparative characterization of S6 kinase $\alpha$ and $\beta$ isoforms expression in mammalian tissues. Biopolym Cell. 2001;17(5):374-9.

20. Savinska LO, Klipa OM, Khoruzenko AI, Shkarina KA, Garifulin OM, Filonenko VV. Generation and characterization of polyclonal antibodies specific to N-terminal extension of p85 isoform of ribosomal protein S6 kinase 1 (p85 S6K1). Biopolym Cell. 2015; 31(4):294-300.

21. Jia CH, Li M, Liu J, Zhao L, Lin J, Lai PL, Zhou X, Zhang Y, Chen ZG, Li HY, Liu AL, Yang $C L$, Gao TM, Jiang $Y$, Bai XC. IKK- $\beta$ mediates hydrogen peroxide induced cell death through p85 S6K1. Cell Death Differ. 2013;20(2):248-58.

22. Comşa Ş, Cîmpean AM, Raica M. The Story of MCF7 Breast Cancer Cell Line: 40 years of Experience in Research. Anticancer Res. 2015;35(6):3147-54.

23. Zhang HH, Lipovsky AI, Dibble CC, Sahin M, Manning $B D$. S6K1 regulates GSK3 under conditions of mTOR-dependent feedback inhibition of Akt. $\mathrm{Mol}$ Cell. 2006;24(2):185-97.

24. Liu L, Li F, Cardelli JA, Martin KA, Blenis J, Huang $S$. Rapamycin inhibits cell motility by suppression of mTOR-mediated S6K1 and 4E-BP1 pathways. Oncogene. 2006;25(53):7029-40.

25. Kyou Kwon J, Kim SJ, Hoon Kim J, Mee Lee K, Ho Chang I. Dual inhibition by S6K1 and Elf4E is essential for controlling cellular growth and invasion in bladder cancer. Urol Oncol. 2014;32(1):51.e2735.

26. Khotskaya YB, Goverdhan A, Shen J, Ponz-Sarvise M, Chang SS, Hsu MC, Wei Y, Xia W, Yu D, Hung MC. S6K1 promotes invasiveness of breast cancer cells in a model of metastasis of triple-negative breast cancer. Am J Transl Res. 2014;6(4):361-76.

27. Chauvin C, Koka V, Nouschi A, Mieulet V, HoareauAveilla C, Dreazen A, Cagnard N, Carpentier W, Kiss $T$, Meyuhas $O$, Pende M. Ribosomal protein S6 kinase activity controls the ribosome biogenesis transcriptional program. Oncogene. 2014;33(4):474-83.

28. Anjum R, Blenis $J$. The RSK family of kinases: emerging roles in cellular signalling. Nat Rev Mol Cell Biol. 2008;9(10):747-58. 
29. Pardo OE, Seckl MJ. S6K2: The Neglected S6 Kinase Family Member. Front Oncol. 2013;3(191). 30. Harrington LS, Findlay GM, Gray A, Tolkacheva T, Wigfield S, Rebholz H, Barnett J, Leslie NR, Cheng S, Shepherd PR, Gout I, Downes CP, Lamb RF. The TSC1-2 tumor suppressor controls insulin-PI3K signaling via regulation of IRS proteins. J Cell Biol. 2004;166(2):213-23.

31. Wan X, Harkavy B, Shen N, Grohar P, Helman LJ. Rapamycin induces feedback activation of Akt signaling through an IGF-1R-dependent mechanism. Oncogene. 2007;26(13):1932-40.

\section{Отримання та характеристика клітинної лінії MCF-7 3 нокаутом ізоформи р85 кінази 1 рибосомального білка S6 (p85-S6K1)}

В. В. Голяр, Н. Я. Гоцуляк, А. І. Хоруженко, I. В. Заєць

Мета. Отримати клітини лінії MCF-7 з нокаутом p85S6K1 ізоформи та оцінити внесок p85-S6K1 в регуляцію проліферації, міграції та виживання клітин. Методи. Вестерн-блот аналіз, система редагування геному CRISPR/Cas9, імунофлуоресцентне фарбування, МТТ-тест, метод «раневої поверхні». Результати. Отримано два клони клітинної лінії MCF-7 з повною відсутністю експресії ізоформи p85-S6K1 та оцінено рівень їх виживання за присутності пероксиду водню, а також ступінь проліферації й міграції цих клітин. Клітини отриманої лінії демонструють зниження життєздатності в умовах оксидативного стресу, сповільнення темпів росту, рухливості та пригнічення рівня фосфорилювання rpS6 за Сер235/236/240/244 за відсутності стимуляції ростовими факторами у порівнянні 3 клітинами дикого типу. Висновки. Поточне дослідження припускає, що ізоформа p85-S6K1 може потенційно бути залученою до регуляції поведінки ракових клітин, сприяючи клітинному росту, міграції та виживанню. Клітинна лінія MCF-7 $з$ нокаутом ізоформи p85-S6K1 може в подальшому бути використа- на для отримання більш повного розуміння різниці у функціонуванні ізоформ p85 та p70 кінази S6K1.

К л юч о в і с л о в а: mTOR/S6K1 сигналінг, CRISPR/ Cas9, ізоформа p85-S6K1.

\section{Получение и характеристика клеточной линии MCF-7 с нокаутом изоформы p85 киназы 1 рибосомального белка S6 (p85-S6K1)}

В. В. Голяр, Н. Я. Гоцуляк, А. И. Хоруженко, И. В. Заец

Цель. Получить клетки линии MCF-7 с нокаутом p85$\mathrm{S} 6 \mathrm{~K} 1$ изоформы и оценить вклад p85-S6K1 в регуляцию пролиферации, миграции и выживания клеток. Методы. Вестерн-блот анализ, система редактирования генома CRISPR/Cas9, иммунофлуоресцентное окрашивание, MTT-тест, метод «раневой поверхности».Результаты. Получено два клона клеточной линии MCF-7 с полным отсутствием экспрессии изо-формы p85-S6K1 и проведено оценку уровня их выживания в присутствии пероксида водорода, а также степени пролиферации и миграции этих клеток. Клетки полученной линии демонстрируют понижение жизнеспособности в условиях оксидативного стресса, уменьшение темпов роста, подвижности и подавление уровня фосфорилирования rpS6 по Cер235/236/240/244 в отсутствие стимуляции ростовыми факторами в сравнении с клетками дикого типа. Выводы. Текущее исследование предполагает, что изоформа p85-S6K1 может потенциально быть вовлеченной в регуляцию поведения раковых клеток, содействуя клеточному росту, миграции и выживанию. Клеточная линия MCF-7 с нокаутом изоформы p85-S6K1 может в дальнейшем быть использована для получения более полного понимания разницы в функционировании изоформ р85 и р70 киназы S6K1.

Кл юч ев ы е с л о в а: $\mathrm{mTOR} / \mathrm{S} 6 \mathrm{~K} 1$ сигналинг, CRISPR/Cas9, изоформа p85-S6K1.

Received 28.03.2019 